\section{«GUARDIANAS DE LA RAZA». EL DISCURSO «NACIONAL-AGRARISTA» Y LA MOVILIZACIÓN POLÍTICA CONSERVADORA DE LA MUJER RURAL ESPAÑOLA (1880-1939)'}

"Guardians of the Race". The "National-Agrarian" discourse and the conservative political mobilization of Spanish rural women (1880-1939)

\author{
TERESA MARÍA ORTEGA LÓPEZ \\ Universidad de Granada \\ tmortega@ugr.es
}

FRANCISCO COBO ROMERO

Universidad de Granada

fcobo@ugr.es

Cómo citar/Citation

Ortega López, T. M. y Cobo Romero, F. (2017)

«Guardianas de la raza». El discurso «nacional-agrarista» y la movilización

política conservadora de la mujer rural española (1880-1939)

Historia y Política, 37, 57-90

doi: https://doi.org/10.18042/hp.37.03

1 La redacción del presente artículo se ha beneficiado de los siguientes Proyectos de Excelencia I+D+I, financiados por el Ministerio de Economía y Competitividad: HAR2012-32539: Discursos e identidades de género en las culturas politicas de la derecha española, 1875-1975, IP: Ángela Cenarro Lagunas y HAR2013-47779-C3-1-P: Movilización colectiva, conflictividad y difusión de actitudes democráticas entre la población rural andaluza durante el tardofranquismo y la transición política, 19621982, IP: Francisco Cobo Romero. 


\title{
Resumen
}

El artículo pretende dirigir la atención hacia el medio rural para estudiar, en el periodo cronológico comprendido entre las décadas finales del siglo XIX y el primer tercio del siglo Xx, la historia de las campesinas, unas «desconocidas» por la historiografía especializada contemporánea. Como trataremos de demostrar, estas mujeres comenzaron a ser vistas y reconocidas como fundamentales por los observadores contemporáneos del periodo que abarca nuestro estudio. Los cambios políticos, sociales, culturales y económicos acontecidos en el periodo señalado facilitaron la progresiva y diferenciada incorporación de las mujeres campesinas a las reflexiones y los discursos que elaboraron numerosos teóricos, analistas sociales y políticos del ámbito ideológico y cultural del tradicionalismo nacionalista. Todos ellos empezaron a destacar el papel esencial que las campesinas deberían cumplir en la realización de un amplio y vasto plan de regeneración nacional y revalorización patria.

\section{Palabras clave}

Campesinas; movilización política; catolicismo; tradicionalismo; éxodo rural.

\begin{abstract}
This article intends to direct the attention towards the rural environment, with the proposal to study, in the chronological period between the late decades of the nineteenth century and the first third of the twentieth century, the history of the peasant women, these authentic unknown for the specialized historiography on contemporary age. As we will try to demonstrate, these peasant women began to be seen and recognized as essential and irreplaceable for the specialized observers of the period covered by our study. The political, social and economic changes that occurred in the above mentioned period, facilitated the gradual and differentiated incorporation of rural women into the reflections and discourses elaborated by many theorists, social analysts and politicians, mostly belonged to the ideological field of nationalist traditionalism. All of them began to highlight the essential role that rural women should play in the realization of a great and vast plan of national regeneration and homeland revaluation.
\end{abstract}

\section{Keywords} exodus.

Peasant woman; political mobilization; catholicism; traditionalism; rural 
I. INTRODUCCIÓN Y PLANTEAMIENTOS INICIALES. II. CORRIENTES DISOLVENTES Y DEVASTADORAS DEL ORDEN SOCIOPOLIITICO TRADICIONAL EN EL MUNDO RURAL. III. LOS PROCESOS DE DESCAMPESINIZACIÓN Y EL SURGIMIENTO DE LA CIUDAD INDUSTRIAL COMO POLO DE ATRACCIÓN PARA LAS NUEVAS GENERACIONES DE JÓVENES CAMPESINAS. IV. EL BUND DEL AGRARISMO CONSERVADOR FRENTE A LAS CORRIENTES DISOLVENTES Y DEVASTADORAS DEL ORDEN SOCIOPOLIITICO TRADICIONAL. V. SENSIBILIZACIÓN PATRIÓTICA, MOVILIZACIÓN POLIITICA Y ENCUADRAMIENTO ASOCIATIVO DE LAS MUJERES CAMPESINAS. VI. A MODO DE CONCLUSIÓN. LA GLORIFICACIÓN DEL MUNDO RURAL-CAMPESINO Y SUS MUJERES DURANTE LA PRIMERA ETAPA DEL FRANQUISMO. BIBLIOGRAFÍA.

\section{INTRODUCCIÓN Y PLANTEAMIENTOS INICIALES}

El movimiento histórico de signo asociativo, político, ideológico y cultural, consistente en la progresiva conversión de la mujer rural en sujeto primordial de movilización política y en objeto preferente de los discursos de la derecha nacionalista y antiliberal, comenzó a perfilarse desde las décadas finales del siglo XIX en buena parte de la Europa Occidental, si bien acentuó sus perfiles más característicos después de la Gran Guerra y a lo largo del agitado y convulso periodo de entreguerras. A la gestación del mencionado proceso contribuyeron, al menos, tres decisivos factores. En primer lugar, la gradual incorporación de la mujer a la actividad laboral, la esfera pública e incluso la vida política y asociativa, acontecida en la mayor parte de las sociedades europeo-occidentales del primer tercio del siglo Xx. En segundo lugar, la emergencia de un poderoso fenómeno de descampesinización y el surgimiento de la ciudad industrial como polo de atracción para las nuevas generaciones de jóvenes campesinas. $Y$ en tercer y último lugar, la conjugación de varias corrientes de desestabilización de la sociedad agraria tradicional europea desde fines del siglo XIX y comienzos del siglo XX, entre las que cabe mencionar las siguientes. De un lado, la modernización y mecanización de las prácticas agrarias y la progresiva sustitución de los roles desempeñados por el hombre y la mujer en las explotaciones tradicionales. Y de otro, la creciente degradación y marginalización de las tareas agrícolas femeninas y su reclusión, o bien en el entorno de las obligaciones propias del mantenimiento del hogar, o bien en la ejecución de las labores más pesadas, menos mecanizadas y más esforzadas. 
Para contrarrestar la perniciosa influencia ejercida por todas estas corrientes disolventes y devastadoras del orden sociopolítico tradicional, los grupos sociales que respaldaban los nuevos sentimientos aflorados desde el nacionalismo organicista e integral más conservador actuaron en correspondencia con las inquietudes manifestadas por las elites políticas tradicionales, especialmente aquellas que se sentían más directamente agredidas por los factores anteriormente descritos. La colaboración de todos ellos se tradujo en la puesta en marcha de toda una serie de estrategias de propagación ideológica y de movilización colectiva, encaminadas a difundir un nuevo discurso de exaltación patriótica instalado sobre una visión idílica de la nación, entendida como un cuerpo cohesionado e imbuido de unos principios espirituales de naturaleza esencialmente rural o agraria ${ }^{2}$.

A lo largo de las siguientes páginas trataremos de demostrar la importancia crucial desempeñada por el intenso atractivo ejercido sobre las jóvenes campesinas y jornaleras españolas por los empleos del sector industrial y terciario, un fenómeno muy extendido por la mayor parte de la Europa Occidental que se vio promovido tanto por la rápida expansión de las grandes urbes como por el desmesurado crecimiento de las clases medias. También intentaremos poner de manifiesto cómo justamente el mencionado fenómeno facilitó la progresiva y diferenciada incorporación de las mujeres campesinas a las reflexiones y especulaciones que iban hilando numerosos teóricos, analistas sociales y políticos del ámbito ideológico y cultural propio del tradicionalismo nacionalista o el organicismo esencialista. Todas estas reflexiones contribuyeron, como se expondrá, a la edificación discursiva de un nuevo modelo de mujer rural. Dicho modelo estuvo instalado sobre la exaltación de sus intrínsecas virtudes, alcanzada mediante la sublimación del trascendental papel del que quedaron ungidas. De acuerdo con los principios sustentadores del nuevo modelo de feminidad rural al que acabamos de hacer mención, las mujeres campesinas habrían sido erigidas en las principales garantes de una reproducción regeneradora y purificante de la raza. El enaltecimiento de las mujeres campesinas las convertiría en portadoras por antonomasia de los valores del ruralismo, el agrarismo, el catolicismo o el tradicionalismo consustancialmente necesarios para acometer con eficacia la contención de aquellas ideologías disolventes del orden rural patriarcal y tradicional que, como ocurriera con el socialismo,

2 La importancia alcanzada por la mujer en los discursos a favor de la recatolización y la preservación de los principios esenciales del nacionalismo corporativista, tradicionalista y conservador ha sido destacada, entre otros autores, por Inmaculada Blasco Herranz. Véase Blasco Herranz (2013). 
el comunismo o el anarquismo, se habían visto impulsadas por la industrialización o por una acelerada urbanización.

Los mencionados discursos del agrarismo tradicionalista y conservador de la mayor parte de la Europa Occidental comenzaron a destacar, desde la década de los ochenta del pasado siglo XIX, el papel esencial que la mujer campesina debería cumplir en la realización de un amplio y vasto plan de regeneración nacional y revalorización patria. La consideración de los valores agraristas y tradicionales más hondamente enraizados en la vida campesina, unida a la cada vez más difundida creencia en el valor demostrado por las políticas de salud pública y las doctrinas eugenésicas en los procesos regeneradores de la nación y la sociedad, condujeron a la exaltación del papel crucial desempeñado por las mujeres campesinas en mitad de una coyuntura histórica juzgada como trascendental y amenazante. La gestación del denominado discurso "nacional-ruralista» contribuyó poderosamente a la sublimación de los fundamentos éticos del conservadurismo y la moral cristiana tradicionalmente asociados a la mujer campesina, erigiendo a esta última en la principal protagonista del medio rural encargada de asegurar la preservación de los valores patrios más intensamente enraizados en un sentimiento nacionalista de carácter organicista, cohesivo y purificador ${ }^{3}$.

\section{CORRIENTES DISOLVENTES Y DEVASTADORAS DEL ORDEN SOCIOPOLITICO TRADICIONAL EN EL MUNDO RURAL}

Desde comienzos del siglo xx, la mujer rural española comenzó a ser juzgada y reconocida como fundamental en el proceso de preservación de los valores patrios más tradicionales por parte de un abultado número de observadores, propagandistas, analistas, sociólogos y científicos sociales más o menos adscritos al ámbito ideológico del fundamentalismo católico y el nacionalismo conservador. Tras superarse la crisis agraria finisecular había aumentado la integración del mercado nacional, la especialización agraria regional y el grado de mercantilización de las explotaciones. Aunque el panorama agrícola era, a la altura de los años veinte y treinta, muy diverso - mientras los

3 Un fenómeno de similares características, consistente en la trabajosa elaboración de un discurso político preocupado por la exaltación de la mujer rural y su consideración como el principal agente portador de los valores del tradicionalismo, el ruralismo y el conservadurismo que deberían hacer frente a los procesos disolventes y debilitantes del tradicional orden social que se vieron acelerados por la industrialización y la modernidad, puede consultarse en Jones (2009). 
subsectores vinícola, hortofrutícola, ganadero y remolachero se renovaban técnicamente y experimentaban una clara expansión, los cultivos cerealistas del interior de España y buena parte de Andalucía siguieron dependiendo de los salarios bajos y el proteccionismo arancelario para ser viables- el crecimiento del producto agrario, que era uno de los principales hilos conductores de los cambios indicados, se mantuvo constante hasta la década de 1930.

Este dinamismo de la economía agraria española estuvo acompañado de profundas mutaciones en la sociedad rural. Unas fueron el resultado acumulativo de tendencias a largo plazo, como el crecimiento del grado de alfabetización de la población asentada en el campo o el aumento de la movilidad interior y exterior posibilitado por el desarrollo de las redes de transporte. Algunas otras estuvieron determinadas por factores coyunturales más directos e inmediatos, como por ejemplo, las recesiones cíclicas padecidas por distintos subsectores agrícolas como consecuencia de la periódica saturación de los mercados. Los fenómenos aludidos dieron paso, de un lado, al éxodo rural a las ciudades y las regiones más industrializadas del país o ultramar, y de otro, a un mayor dinamismo en el mercado de la tierra y con él, a la creación o desaparición de pequeñas propiedades, así como a la extensión de nuevas figuras contractuales. Finalmente, otra causa de las mutaciones que se registraron en el campo español en las fechas indicadas estuvo motivada por la progresiva movilización y politización de segmentos crecientes de la sociedad rural, especialmente a partir de la crisis del 98 . Desde la derrota española en la guerra hispano-norteamericana proliferaron discursos plurales sobre la sociedad rural que denunciaban los males del campo y sus moradores. El tono pesimista de la época inundó la opinión pública. Tanto en la prensa como en los medios políticos aparecieron voces críticas que empezaban a cuestionar los proyectos e instituciones del Estado liberal. En el caso concreto de la agricultura, una destacada figura como la de Joaquín Costa reclamaba la modernización generalizada del sector y el fin de la agricultura tradicional, incluidos los abusos caciquiles y oligárquicos ${ }^{4}$. La aparición, desde entonces, de asociaciones reivindicativas, o simplemente autónomas, de cultivadores — propietarios o arrendatarios - y jornaleros, dio vida a la "cuestión agraria» o al «problema agrario» español.

4 Algunos otros destacados estudiosos y políticos españoles, preocupados por el fomento de la agricultura y la mejora integral de las condiciones de vida o el desarrollo cultural de la población rural, precedieron a Costa en el señalamiento de los males que aquejaban nuestro sector primario. Uno de ellos fue Fermín Caballero. Algunas aproximaciones a su obra y pensamiento pueden consultarse en Urquijo-Goitia y Paniagua (2011) y Vallejos Izquierdo (2014). 
El avance por toda la geografía rural española de movimientos huelguísticos inspirados por unas ideologías revolucionarias cada vez más asentadas en las áreas predominantemente agrícolas del país ${ }^{5}$ y el temor que dicho avance generó entre la clase política, constituyeron la base del "giro ruralista» del ambiente intelectual y de las fuerzas políticas de los años que siguieron al «Desastre». La principal novedad que se derivó de aquel giro fue la adopción de una política «regeneracionista». Frente a la política represiva que los Gobiernos dinásticos exhibieron hasta ese momento para contener las acciones «subversivas» del campesinado español, desde la primera década del siglo Xx la «cuestión agraria» comenzó a enfocarse mediante un programa de intervenciones públicas que se inspiró en el reformismo social. La fuerza fue sustituida entonces, aunque la maquinaria represiva y coactiva del régimen de la Restauración nunca dejase de actuar, por el «ingenierismo social». En la España de la derrota humillante frente al imperialismo norteamericano arraigaron con fuerza las demandas que exigían acometer la modernización de la sociedad rural, toda vez que se había constatado su fracaso - simbolizado en Castilla-, dando «un golpe de timón» a la política agraria. Tanto los productores agrarios, cada vez más movilizados, como buena parte de la clase política, imbuida del discurso regeneracionista difundido por la literatura ensayística y novelística de la época, eran conscientes que las respuestas a ambas demandas no podían venir de la mano de las viejas políticas liberales. Estas se presentaban, a la altura de 1900, caducas e inútiles para emprender un viraje reclamado como necesario y urgente.

El prólogo al final de la sociedad liberal-rural tradicional decimonónica empezó a escribirse, pues, con una nueva letra. El regeneracionismo y el reformismo social colocaron a la sociedad rural, la quintaesencia de la nación, en el eje de su análisis. Al igual que ocurriera en otros países europeos, en España se multiplicaron los escritos que oponían la ciudad, conceptuada como degradante, cosmopolita y desarraigada, a un campo que constituía, desde un punto de vista biológico y cultural, el semillero de la vitalidad racial y el principal sostén de la prosperidad económica ${ }^{6}$. La modernización del agro español, entendida en un sentido de mejora del capital humano y de aumento de la tecnificación de las labores agrarias, se convirtió en la clave para superar el «atraso secular» con el que muchos tachaban la situación de la agricultura y del campesinado en aquel fin de siècle. Conservadores y liberales articularon entonces soluciones inéditas, procedentes tanto de la ingeniería agronómica, que vio crecer su prestigio desde el cambio de siglo entre la comunidad

Cobo Romero (2010): 121-144.

6 Consúltese Puhle (1986); Retallack (1988); Blackbourn (1980) y Jones (2009). 
científica española, como de otras corrientes de pensamiento que abogaban por el fomento de la pequeña propiedad para garantizar, por un lado, la formación técnica y económica del campesinado, y por otro, el aumento de la producción y la solidificación del deseado consenso social.

Numerosas propuestas envueltas en un lenguaje pragmático y cientificista terminaron conformando un programa de intervenciones públicas. Justamente en el análisis de este "programa de soluciones» hayamos el interés que despertaron las campesinas para las autoridades del país. Ellas y la economía doméstica pasaron a formar parte esencial y activa, desde los albores del mencionado siglo $\mathrm{Xx}$, de las políticas con las que se trató de hacer frente a la denominada «cuestión agraria». Las campesinas se constituyeron en pieza clave de la política regeneracionista encaminada a la modernización de la sociedad rural. Así lo vemos reflejado en cuantos estudios fueron realizados por los ingenieros agrónomos de la época. Aquellas mujeres campesinas ocuparon un capítulo importante en las investigaciones de estos expertos. Según se indicaba en sus trabajos, esas mujeres eran esenciales para garantizar la buena marcha de la agricultura familiar. Su participación en las pequeñas y medianas explotaciones familiares contribuiría a resolver los problemas sociales y económicos que aquejaban al campo. Su trabajo garantizaría la supervivencia de dichas explotaciones, lo cual favorecería la restauración de la estabilidad social, devolviendo a los campos españoles la paz y la armonía quebradas por las múltiples mutaciones anteriormente señaladas. Además, el trabajo de las mujeres campesinas generaría estabilidad y prosperidad económica, pues permitiría incrementar el ahorro agrario para que posteriormente pudiese ser transferirlo hacia los sectores económicos de la industria y los servicios.

De esta forma las mujeres rurales pasaron de ser actores históricos invisibles a regentar un destacado un lugar en el panorama político nacional. Al igual que los agricultores y campesinos, aquellas mujeres se convirtieron en protagonistas de los discursos políticos de la España del primer tercio del siglo Xx. Especialmente de aquellos discursos con una tonalidad esencialmente tradicional y «ruralista» que construyeron y difundieron las culturas políticas conservadoras, católicas y antiliberales en las décadas que precedieron a la Guerra Civil, como medio para amortiguar los perturbadores efectos causados por la emergencia de las masas en la política propiciada por el éxodo rural y el avance de la industrialización 7 . Se trataba de un fenómeno que, íntimamente unido a la idea del Heimat y la exaltación de la centralidad ocupada por las variedades culturales del localismo en la definición de la identidad nacional, centró su mirada en los paisajes, las tradiciones populares, el rico y

Fusi (1991): 327-342. 
variado folclore regional, los ritos ancestrales, las lenguas y los dialectos. Todos ellos fueron concebidos como los principales elementos que componían las características de unas comunidades en trance de desaparecer, y que se consideraron reflejos de un Volksgeist inalterable 8 . Un fenómeno que vendría asociado a la progresiva nacionalización de los valores naturales llevada a cabo por los emergentes Estados nacionales europeos y por los diferentes movimientos regionalistas?.

La retórica de este discurso «nacional-ruralista» no estaba dirigida exclusivamente a los hombres del campo. Para el «nacional-ruralismo» todos los habitantes del mundo rural, y por tanto, también las campesinas, estaban llamados a formar parte del "esfuerzo colectivo» - expresión y concepto relevantes de propuestas políticas ultranacionalistas y fascistas- que debía emprender la nación para alcanzar el engrandecimiento y la prosperidad futura de la patria. En este sentido el «nacional-ruralismo», pese a su naturaleza antifeminista, mostró un gran interés por las mujeres rurales. Hacia las campesinas manifestó un claro afán adoctrinador, propagandístico y movilizador. Su pretensión principal era mantener fijada a la mujer rural en el campo y en el hogar. Pretensión que atendía, como hemos advertido antes, a intereses muy diversos. Desde los puramente políticos y económicos, a los religiosos y culturales.

En las primeras décadas del siglo $\mathrm{xx}$, el flujo de mujeres de las zonas rurales a las urbanas se había convertido en un fenómeno cada vez más frecuente. Atraídas por las posibilidades laborales y de ocio (teatros, variedades, bailes) que ofrecían las ciudades, y también animadas por mejores «ofertas de matrimonio", muchas jóvenes campesinas decidieron dejar atrás la vida dura del campo. La realidad rural estaba lejos de las idílicas escenas representadas y evocadas por la literatura bucólica decimonónica y de principios del siglo siguiente ${ }^{10}$. Para las culturas políticas contrarrevolucionarias, esta decisión de abandonar el campo tan practicada entre las jóvenes del medio rural ponía en peligro no solo la supervivencia de las explotaciones agrarias, sino,

8 Al respecto, Applegate (1990) y Confino (1997). Una aproximación a la instrumentalización política de la «patria local» en España y Alemania en Núñez Seixas (2008). Respecto a la literatura regional caracterizada como modernismo casticista, Calvo (2001). La explosión violenta de este modelo provinciano/totalitario en Ugarte (1998).

9 Para el caso alemán y entre una extensa bibliografía, puede consultarse el análisis historiográfico de las aportaciones más recientes que efectúa Motadel (2008). Véase también Lekan (2004).

10 Díez de Revenga (1998). 
asimismo, la estabilidad social y económica que mantenía en pie a la nación. La «fuga» de las jóvenes mujeres campesinas hacia la ciudad fue vista, además, como un fenómeno que amenazaba la supervivencia de viejos valores patriarcales y formas tradicionales de vida. Los miedos al respecto no eran infundados. En la Belle Époque, las costumbres se innovaron y se diversificaron. Nuevos y amenazantes valores culturales se imponían vigorosamente en la mayor parte de las sociedades occidentales. Entre las mujeres prendió con fuerza el nuevo arquetipo femenino que vio la luz tras los años que siguieron a la Primera Guerra Mundial: la «mujer moderna» de los «felices años veinte». Una mujer instruida, maquillada, peinada a lo garçonne, capacitada para ejercer una profesión, más libre en sus costumbres (con proyectos personales, y con simpatías y opiniones políticas propias) y sin las ataduras generadas por trasnochados convencionalismos ${ }^{11}$. Aunque este modelo de "mujer moderna" no se adaptaba a la mayoría de las mujeres españolas, tal vez ni siquiera a una minoría significativa, generó tal estado de ansiedad, inquietud y angustia entre amplios círculos del tradicionalismo cultural y político que pronto se articuló, desde multitud de ámbitos (intelectual, científico, político), una nueva retórica y un variado repertorio de respuestas defensivas en su contra ${ }^{12}$. Nadie quedó, pues, indiferente.

\section{LOS PROCESOS DE DESCAMPESINIZACIÓN Y EL SURGIMIENTO DE LA CIUDAD INDUSTRIAL COMO POLO DE ATRACCIÓN PARA LAS NUEVAS GENERACIONES DE JÓVENES CAMPESINAS}

Desde 1910, los movimientos campo-ciudad se encargaron de modificar notablemente el mapa residencial de la población española y actuaron como un destacado factor de crecimiento urbano. Este comportamiento no solo continuó sino que se acentuó en la década siguiente y únicamente se vio interrumpido con el inicio de la Guerra Civil española ${ }^{13}$. Los destinos mayoritarios de aquel desplazamiento fueron en su gran mayoría las capitales de

11 Ramos (2002): 143.

12 Aresti (2001). Esta misma autora evidencia cómo las transformaciones sociales y culturales acontecidas en aquellos años hicieron que se tambalearan las tradicionales relaciones entre hombres y mujeres, las expectativas de los varones hacia ellas y los atributos que conformaban el ideal de feminidad, lo que provocó en ocasiones respuestas cargadas de violencia. Véase Aresti (2010) y el artículo de Ortega López (2010).

13 Camarero (1993): 188. 
provincia $^{14}$, las cuales absorbieron prácticamente en su totalidad las migraciones internas en el período prebélico ${ }^{15}$. Desde entonces, la relación entre el volumen de población del campo y las ciudades comenzó a inclinarse a favor de los municipios superiores a los 10000 habitantes. En consecuencia, en 1930, y como advertía el reformista social de principios de siglo, Rafael de Roda y Jiménez, el tradicional equilibrio entre campo y ciudad, entre población urbana y población rural, había tocado a su fin y se tornaba imposible ${ }^{16}$. En su lugar se impuso un nuevo reequilibrio espacial de los recursos humanos determinado por las modernas estructuras productivas que empezaban a consolidarse en España.

Pese a que la emigración campo-ciudad estuvo mayoritariamente compuesta por hombres, también contó con un porcentaje altamente significativo de mujeres. Las residentes en las ciudades aumentaron a un ritmo apreciable. El proceso de industrialización y diversificación económica que conoció el país en las décadas iniciales del siglo Xx favoreció el trasvase de mujeres del campo a la ciudad. Este cambio económico redujo considerablemente el peso de aquellas mujeres de origen campesino y jornalero en los municipios rurales de menos de diez mil habitantes. En algunas regiones españolas, como fue el caso de Cataluña, La Rioja, Extremadura, Galicia, Madrid, País Valenciano y País Vasco, esa reducción se situó entre el 11 y el 18 \%. Estas mismas regiones fueron, precisamente, las que registraron en 1930 un mayor aumento porcentual de la población femenina residente en municipios urbanos respecto a 1900. En efecto, prácticamente todas las regiones mencionadas, junto con Andalucía, Asturias, Baleares y Canarias, vieron cómo las mujeres cuya residencia estaba localizada en municipios de más de diez mil habitantes aumentaron por encima de un $6 \%$. Incluso en algunos casos, como ocurrió en Canarias, Cataluña, La Rioja y el País Vasco, ese porcentaje superó el 12 \%.

La movilidad de las mujeres rurales fue, en consecuencia, más que evidente. El cambio de residencia, el paso del campo a la ciudad era, por tanto, a inicios del siglo XX, una opción real que empezaba a estar en la mente de

14 No obstante, hay que señalar que según el censo de población de 1920, existían en España cincuenta y cuatro municipios que, sin ser capitales de provincia, constituían grandes aglomeraciones de población al contar con más de veinte mil habitantes. Era el caso, entre otras, de ciudades como Lorca en Murcia, La Línea en Cádiz, Vigo en Pontevedra, Sabadell, Tarrasa, Manresa y Mataró en Barcelona, y Tortosa y Reus, en Tarragona. Estas ciudades, como muchas otras repartidas por la geografía de España, absorbían y atraían a millares de familias e individuos del campo. Véase Elías (1927): 8.

15 Camarero (1993): 189.

16 De Roda y Jiménez (1926): 6-7. 
muchas de aquellas mujeres de origen campesino y jornalero. Qué causas estaban detrás de aquel éxodo rural. Muchas y variadas fueron las explicaciones que ofrecieron los especialistas de la época sobre la emigración femenina del campo. Intensos y prolongados debates, como señalaba Severino Aznar en el prólogo de su libro Despoblación y colonización (1930), se sucedieron en la España del primer tercio de siglo para localizar las causas del éxodo de las campesinas. La mayoría centraron su explicación en la fascinación "engañosa» que las ciudades despertaban entre las mujeres más jóvenes. Esta explicación la ofreció, entre otros, el reverendo padre de Acción Católica, Victorino Feliz (1934: 17), quien señalaba al respecto lo siguiente: «[...] ellas [las jóvenes campesinas] eran las primeras en adoptar la determinación de abandonar el campo y marchar a la ciudad, y los hombres no hacen sino ir tras ellas. Sí, muchas se dejan prender en el espejo de las ciudades. Y el hombre sigue a la mujer a quien atrae el espejo: vieja historia».

Este éxodo se constató en gran medida en las mujeres más jóvenes ocupadas, muy especialmente, en las explotaciones agrarias de carácter familiar. Desde los años diez y veinte del siglo pasado, un número nada despreciable de jóvenes campesinas dejó tras de sí el mundo rural/agrario para aventurarse en la ciudad en busca de una nueva actividad profesional que fuera menos dura que las interminables jornadas laborales del campo. Como advertía José Elías Molins (1927: 14):

¡Cómo habían de seguir en el campo muchas mujeres jóvenes de algunas comarcas rurales, que en sus casas no gozaban más que del sustento, no siempre variado y abundante, y de un humilde vestido, privadas de esparcimiento, y de salario, cuando se les brindaba ir a la fábrica o taller del pueblo o ciudad vecina y ganar buenos semanales con un trabajo poco penoso con el auxilio de las máquinas y útiles modernos! Por otra parte, ¡cómo no han de abandonar por idéntico motivo el campo millares de mujeres en la granja, la masía, o destartalado caserón rural, cuando son solicitadas para ir a prestar sus servicios a la ciudad a cambio del sustento y buenas mesadas!

Las penosas condiciones de vida y trabajo en el campo hicieron más atractiva la ciudad. Un espacio que les ofrecía multitud de posibilidades. Por un lado, la ciudad les proporcionaba un rápido empleo en la industria y en el comercio, pero también en el servicio doméstico. Miles de muchachas llegadas del interior rural se emplearon como criadas, nodrizas o ama de llaves de una emergente clase media urbana que necesitaba de sus labores y servicios. Por otro lado, la ocupación en la ciudad era una vía ideal para promocionarse económica y socialmente, sin necesidad de pasar por el matrimonio. 
Y en el caso de optar por el camino de la nupcialidad, probablemente las posibilidades de encontrar una pareja adecuada fuesen mayores que en el pueblo o en la aldea, permitiendo lograr una cierta promoción de su modesta condición social.

Detrás de la decisión de abandonar el campo había, no obstante, algo más que necesidades puramente económicas o el deseo de encontrar nuevas oportunidades laborales y sociales. Las jóvenes que emigraron a la ciudad lo hicieron también por otras razones no tan materiales. Muy probablemente muchas se marcharon por su malestar, latente y/o manifiesto, con la invisibilidad y la subordinación a que las condenaba una organización social patriarcal que perpetuaba las diferencias entre hombres y mujeres y, sobre todo, el papel subsidiario desempeñado por estas últimas. Tal organización conformaba para las mujeres rurales una situación de aislamiento social, de inexistencia de un horizonte personal individual, de subordinación económica y de dependencia familiar. Esto era así porque su trabajo fuera del hogar no se veía como un signo de promoción y de independencia personal, solo se consideraba una «ayuda» y jamás se valoraba como equivalente al realizado por los hombres aunque fuera igual de duro. Sus labores se estimaban solo como un "complemento" a las actividades que hacía el padre o, en su caso, el marido. Desde esta perspectiva, y tal y como rezaba en el imaginario individual y colectivo de las comunidades rurales, las mujeres campesinas solo obtenían reconocimiento social y posibilidad de autoestima realizando las labores propias de la esfera reproductiva, es decir, adoptando el rol que se les atribuía como madres y esposas sumisas y abnegadas, como sufridoras de todos los males familiares y sociales. Así, las mujeres no desarrollaban una individualidad personal y podían ser consideradas como seres intercambiables, reemplazables o sustituibles por otra mujer (tía, abuela, madre, hermana, vecina) en su función de criar hijos, cuidar de la casa y trabajar — como ayuda - en el campo ${ }^{17}$.

Todo parece indicar, independientemente de cuál o cuáles fueran las razones, que en el primer tercio del siglo xx hubo un importante desplazamiento poblacional de carácter inter e intraprovincial, así como regional. La gran mayoría de las jóvenes y adolescentes que decidieron abandonar el campo se trasladaron mayoritariamente a las capitales de provincia, o a las ciudades de mayor población, en las que las oportunidades de empleo eran mayores. En las ciudades, esas muchachas procedentes del medio rural más o menos próximo, casi siempre solteras y con un bajo nivel de educación, utilizaron el

Esta realidad que ha marcado nuestra historia, e incluso nuestro presente más inmediato, proviene de la ponencia realizada por Arnáiz (1999): 65. 
servicio doméstico como primera y, en ocasiones, única alternativa para mejorar su precaria situación económica, o bien como vía para la obtención de una autonomía personal frente a su papel subordinado en la agricultura familiar. De hecho, y como advierte Rosa Capel, en 1930 el servicio doméstico ya ocupaba el segundo lugar en lo que respecta a la población activa femenina, por delante de la agricultura y por detrás de la industria ${ }^{18}$.

La decisión de «la marcha» no tardó en desatar la preocupación, los miedos, las iras y las denuncias de muchos ${ }^{19}$. Por un lado, la «huida» a la ciudad de las jóvenes quebrantaba aquel orden social/local profundamente sexista característico de las comunidades rurales, lo que implicaba, al mismo tiempo, el abandono de la sumisión patriarcal en el seno de las familias agrarias. Una sumisión que tenía su expresión más relevante en el marco de las explotaciones familiares por su condición de "ayuda familiar». Y por otro, aquel éxodo femenino entrañaba para muchos otras consecuencias no menos «perversas». En efecto, en el mundo rural comenzó a constatarse un fenómeno que años más tarde sería un elemento característico de la modernización social española de los años sesenta y setenta del siglo xx: el de la masculinización de las pequeñas localidades y municipios. En 1930 los municipios menores de tres mil habitantes de prácticamente todas las regiones españolas habían sido los que con mayor intensidad vieron descender su población femenina adolescente, es decir, aquella comprendida entre los catorce y los veinte años. Los casos más llamativos en este sentido fueron los correspondientes a Aragón, Asturias, las dos Castillas, Cataluña, Galicia, Valencia, el País Vasco y Navarra. En estas regiones el número de varones comprendidos también entre los dieciséis y los veinte años superaba ampliamente al de las mujeres. Incluso en esas mismas regiones, el déficit de mujeres era igualmente apreciable en los tramos de edad comprendidos entre los veinticinco y los treinta y cinco años. El fenómeno de la masculinización rural fue igualmente apreciable en los municipios semiurbanos de Aragón y Castilla la Nueva. En estas dos regiones la relación de mujeres por cada cien varones siguió siendo negativa en los tramos de edad más jóvenes de los municipios que contabilizaban una población comprendida entre los tres mil y los diez mil habitantes. El resto de las regiones arrojó un saldo positivo. Por su parte, en los municipios urbanos la presencia de mujeres jóvenes fue siempre superior a la de los varones, hasta el punto de que podemos hablar de un nuevo fenómeno, el de la «feminización del mundo urbano». En prácticamente todas las ciudades españolas de más de diez mil habitantes, con las excepciones de las de Murcia y Galicia, la

18 Capel (1980): 11.

19 Ruiz de Tudanca (1928): 185-187. 
proporción de mujeres de entre catorce y veinte años superó visiblemente a la de los hombres.

Esta «ruptura» de las mujeres más jóvenes con el medio rural dejaba sin esposas a los titulares y a los potenciales titulares (herederos varones) de las explotaciones familiares agrícolas, lo que tendría severas consecuencias sociales y económicas a la postre. El éxodo rural de las féminas más jóvenes, una mano de obra invisible pero tremendamente útil, no solo dificultaría la reproducción y el recambio generacional (con el consiguiente deterioro de la raza) ante la progresiva masculinización y envejecimiento del campo, sino que también provocaría el derrumbe, al hacerlo insostenible, de lo que podríamos considerar como los pilares básicos de la economía del país, es decir, las pequeñas y medianas explotaciones familiares.

Planteado así el problema de la emigración femenina, como un hecho hondamente preocupante, no extraña que algunos clamaran: «iNo vayáis a la ciudad! $\aleph^{20}$. Y que otros, como Elías de Molins, presidente de Acción de Defensa Agraria, procediera en 1928 a la constitución en Barcelona, bajo los auspicios e iniciativa del Ayuntamiento de esta ciudad y de la Diputación Provincial, de la Junta de Reintegración al Campo, una institución destinada a atajar, entre otras cosas, el éxodo masculino y femenino del mundo rural ${ }^{21}$. Había una convicción que empezó a ser aceptada y asumida por la clase política española y muy repetida por el discurso agrarista del momento. Sin mujeres jóvenes y casaderas en el mundo rural, los hombres terminarían marchándose a la ciudad y el campo, fuente de riqueza, bienestar y vida, se derrumbaría ${ }^{22}$. Se hacía del todo necesario, como señalaba el diputado del partido liberal y alcalde de la Coruña, José Sánchez Anido, vizconde de San Antonio, «anudar el lazo que liga a la mujer a la tierra, que será también — por el amor a la mujer — el que ligue al hombre a su terruño, foco de prosperidad individual y nacional $»^{23}$. Porque, como indicaba también A. de Mirabal, "todo depende, en una nación eminentemente agrícola como la nuestra, de la prosperidad agrícola, que es imposible conseguir si el factor principal de la producción económica, el hombre, escasea» ${ }^{24}$.

El auge alcanzado por las elevadas tasas de natalidad entre la población de las clases trabajadoras industriales y el proceso de ralentización de las tasas

20 Bellver, A. (1924): «La vuelta a los campos», La Tierra. Órgano de la Federación de Sindicatos Católico-Agrarios de Córdoba, 1033, 5 de noviembre, p. 1.

21 Utrillo (1952): 434.

22 El defensor de Córdoba. Diario católico de noticias, 15 de noviembre de 1922, p. 1.

$23 A B C$ (Madrid), 21 de febrero de 1928, p. 22.

24 A. de Mirabal, "Crónica Social», Revista Católica de Cuestiones Sociales, núm. 358, octubre de 1924, pp. 245-257, p. 248. 
reproductivas entre la población rural se unieron pronto a la rápida difusión de los discursos ideológicos defendidos por las culturas políticas democratizadoras o revolucionarias. Tales discursos, instalados sobre la exaltación del asociacionismo colectivista y la lucha de clases, se tornaron cada vez más amenazadores respecto de los tradicionales discursos del nacionalismo y el patriotismo corporativista o católico-tradicionalista. El resultado de todo ello no fue otro que la creciente animadversión, expresada por los representantes políticos y culturales de los grupos sociales rurales más conservadores, contra los cambios y transformaciones que caracterizaron el inicio del siglo Xx.

\section{EL BUND DEL AGRARISMO CONSERVADOR FRENTE A LAS CORRIENTES DISOLVENTES Y DEVASTADORAS DEL ORDEN SOCIOPOLIITICO TRADICIONAL}

Para contrarrestar la perniciosa influencia ejercida por todas estas corrientes disolventes y devastadoras del orden sociopolítico tradicional, los grupos sociales que respaldaban los nuevos sentimientos aflorados desde el nacionalismo organicista e integral más conservador actuaron en correspondencia con las elites políticas tradicionales que se sentían más directamente agredidas por los factores anteriormente descritos. La colaboración de todos ellos se tradujo en la puesta en marcha de toda una serie de estrategias de propagación ideológica y de movilización colectiva encaminadas a difundir un nuevo discurso de exaltación patriótica instalado sobre una visión idílica de la nación, entendida como un cuerpo homogéneo y unificado, imbuido de unos principios espirituales legados por una tradición firmemente arraigada en una serie de rancios valores predominantemente agrarios.

Gracias a la incorporación de las nuevas teorizaciones eugenésicas sobre la importancia de las políticas públicas en la regulación de las prácticas reproductivas de la sociedad, comenzó a difundirse entre amplios estratos de los grupos sociales más conservadores la creencia en la necesidad de promover la reproductividad de los grupos sociales intermedios del campesinado, así como de las clases intelectualmente mejor preparadas y más capacitadas para defender la pureza de los principios espirituales y éticos del nacionalismo tradicional. De esta manera se pretendía contrarrestar el imparable auge experimentado por el crecimiento demográfico de las clases populares, consideradas como potencialmente peligrosas y peligrosamente antinacionales, debido al intenso proceso de degradación moral, psicológica y anímica al que se habrían visto sometidas como consecuencia de los profundos trastornos derivados de los rápidos procesos de industrialización y del hondo desarraigo que tales procesos habrían 
desencadenado ${ }^{25}$. Asimismo, dentro de estas preocupaciones de naturaleza esencialmente eugenésica o de ingeniería biológica, numerosos teóricos, analistas sociales y políticos del ámbito ideológico y cultural propio del conservadurismo liberal y del tradicionalismo nacionalista, empezaron a destacar el papel esencial que la mujer campesina debería cumplir en la realización de un amplio y vasto plan de regeneración nacional y revalorización patria.

La exaltación de los valores del agrarismo y el tradicionalismo más consustancialmente enraizados en la vida campesina condujo a la sublimación del papel crucial desempeñado por la mujer rural en la preservación de los más hondos valores de la raza hispana. El pensamiento católico-tradicionalista y el agrarismo conservador comenzaron a considerarla como el principal agente encargado de asegurar la preservación de los valores patrios más hondamente enraizados en un sentimiento nacionalista cohesivo y purificador, considerado como el más firme baluarte frente a las corrientes debilitantes y disgregadoras del socialismo, la democracia, el mundo urbano, los valores materiales, el individualismo o el internacionalismo antipatriótico y antinacional.

Para ello, se entendió como una necesidad imperiosa la propagación de la enseñanza entre la población rural. La acción educativa se encaminó, muy especialmente, a formar labradoras instruidas e inteligentes, conscientes de su importantísimo papel en la gestión de una explotación agrícola, y dotadas de todas las condiciones y habilidades para dirigir y administrar la casa pero también para secundar activamente al hombre del campo en todos los trabajos. Los ingenieros agrónomos, así como un destacado grupo de insignes pedagogos y legisladores, llegaron a la conclusión de que, con una buena formación profesional, las hijas de los propietarios, arrendatarios y obreros agrícolas abandonarían todos los deseos de dejar el campo y marcharse hacia los centros urbanos, obligando, de paso, a los hombres, a permanecer en sus lugares de origen. Como «trabajadoras responsables» garantizarían el arraigo a la tierra, al tiempo que contribuirían poderosamente a labrar la felicidad y el bienestar del hogar rural, fomentando así el desarrollo agropecuario.

La escasa o nula enseñanza que recibían las niñas y muchachas de las zonas rurales en su periodo de escolarización sobre temas de agricultura, unida a la falta de oportunidades de empleo en sus entornos más inmediatos, fueron consideradas como las principales causas de la marcha de las jóvenes del campo. El pedagogo católico José Rosell se preguntaba: «¿Cuáles son las causas de que se ame tan poco la vida rural, la verdadera vida, y de que deserten de ella tantos y tantas para ir a enterrarse en los centros fabriles y populosos?». Y a continuación, él mismo se daba la respuesta a su

25 Véase Jones (2009) y Weindling (1989). 
pregunta: «Una de las causas, tal vez la principal, es la mala educación» ${ }^{26}$. Para muchos, la falta de instrucción y preparación de las jóvenes del mundo rural les deparaba una suerte triste y las obligaba a marcharse lejos de sus casas:

¿Qué papel desempeñan las mujeres de nuestros campos? ¿Qué vida hacen? ¿En qué despliegan sus energías? La mayor parte de ellas emigran a los grandes centros de población para formar la servidumbre de las clases sociales más acomodadas; gran parte se confunden entre la turbamulta sin saberse qué será de ellas. En cuanto a las que, por distintas causas, quedan apegadas al terruño, llevan la vida más monótona ${ }^{27}$.

En 1901, la también pedagoga Alicia Pestana defendía con gran pasión «fomentar y favorecer el amor a la tierra, por la difusión y desenvolvimiento de aquella compleja enseñanza que la interpreta y la ennoblece», por considerarlo el remedio más firme para frenar aquel «extenso e intenso mal» que significaba la marcha a la ciudad de las más jóvenes mujeres del $\mathrm{campo}^{28}$. Al igual que el de Alicia Pestana, desde comienzos del siglo Xx hubo en nuestro país multitud de llamamientos que se mostraban partidarios de la Formación Profesional y de la instrucción de las mujeres campesinas en saberes diversos para convertirlas en agentes de la modernidad (técnica) agraria y de la prosperidad de la agricultura ${ }^{29}$. Entre los pedagogos, analistas sociales, ingenieros agrónomos y políticos prendió la necesidad de destruir los viejos moldes y rutinas en las que estaban sumidas las tareas de aquellas mujeres. Para ello se hacía del todo imprescindible educar a las hijas de los propietarios rurales en todas aquellas disciplinas que conducían a un conocimiento racional y científico de la agricultura y su desempeño profesional. Se habían convencido, como antes lo habían hecho sus colegas europeos, de que «la colaboración inteligente por parte de aquellas contribuiría eficazmente a acelerar los progresos de la agricultura ${ }^{30}$, y que esa instrucción permitiría a las campesinas cumplir adecuadamente las múltiples funciones asignadas a su sexo en el medio rural. Como advertía el maestro y pedagogo Félix Martí Alpera, el papel que jugaban estas mujeres era superior incluso al de las que habitaban en las

\footnotetext{
26 Rosell (1907): 179.

27 El Progreso agrícola y pecuario, núm. 480, 22 de abril de 1906, p. 226.

28 Pestana (1901): 225.

29 Rosell (1909): 751-752.

30 Boletín de la Institución Libre de Enseñanza. Año XXXVIII, núm. 654, 30 de septiembre de 1914, p. 266.
} 
ciudades. Sus funciones eran mucho más complejas y no se reducían en exclusiva al interior del hogar y al cuidado de la familia:

En el campo, la mujer gobierna la casa, prepara la ropa y la comida, y cría a sus hijos como la mujer de la ciudad, pero además desempeña funciones importantísimas de que se halla libre ésta. Ella cuida de los animales de corral y frecuentemente de las bestias de labor; hace cultivar o cultiva ella misma el jardín y la huerta inmediatos a la casa; es ella la que lleva a cabo casi todas las compras y aún casi todas las ventas, y es siempre una activa colaboradora del hombre del campo en todos sus trabajos y en todas sus empresas ${ }^{31}$.

El agrarismo político emergente en la España de comienzos del siglo Xx también incluyó a las mujeres agrarias en su programa, convirtiéndolas en las principales destinatarias de sus planteamientos reivindicativos: «En el movimiento que empieza a iniciarse en España debe no olvidarse que la mujer ocupa un lugar de preeminencia innegable, y que fomentar y desarrollar la educación de la mujer agrícola, juntamente con la enseñanza general agraria, deben ser los primeros cuidados de quienes están encargados de encauzar y dirigir el espíritu agrícola del país $\aleph^{32}$.

A tenor de los excelentes resultados obtenidos por los países de nuestro entorno, algunos políticos agraristas españoles se convirtieron en grandes defensores de la enseñanza de las jóvenes del campo. Para el senador Luis Redonet y López Dóriga la educación «señoril» que recibían las hijas de los labradores en conventos, colegios y liceos era «perfectamente inútil». Había que reaccionar contra esa estéril formación en piano, moda, dibujo, idiomas, literatura, etc. "¡Menos piano y más campo!»33, era lo que precisaba, a su entender, la mujer campesina. Es por ello que se mostró partidario de establecer la enseñanza agraria como obligatoria en todos los colegios femeninos — siguiendo el ejemplo de Inglaterra, pero también el de Alemania, Francia y Bélgica一, "para despertar en ella el amor al campo y capacitarla para la dirección de una granja y evitar su huida a la ciudad $\aleph^{34}$.

31 Martí Alpera (1911): 84-85.

32 Diario de Córdoba de comercio, industria, administración, noticias y avisos. Año LIV, núm. 18 028, 5 de julio de 1909, p. 2.

33 La expresión «Menos piano y más campo» fue formulada por José Rosell en un artículo realizado para la sección «Veladas rurales de educación popular y agrícola» de la revista El Progreso agrícola y pecuario, núm. 476, 22 de marzo de 1906, p. 164.

34 Redonet y López (1916): 34. 
No era él el único que pensaba de esa manera. El diputado gallego José Sánchez Anido señalaba en 1922: «La causa del éxodo rural y del atraso de los labriegos está, en muy buena medida, en la ignorancia de la mujer campesina ${ }^{35}$. Esta afirmación la dejaba expuesta en su libro Educación campesina, un trabajo en el que dedicaba un amplio capítulo a la «Enseñanza agrícola de la mujer ${ }^{36}$. El libro del conde de San Antonio propugnaba la necesidad perentoria de la formación profesional de las campesinas como el mejor medio "para asegurar para siempre el progreso agrícola del país» ${ }^{37}$. Daba también justa preferencia a las cátedras ambulantes aunque también reclamaba con inflada fe patriótica a las autoridades que pusieran los jalones de la enseñanza agrícola femenina en todos los niveles del sistema educativo (primaria, media y superior): «Quien establezca en España, no en el papel, sino dándole vida real, la enseñanza agrícola para la mujer, merecerá la gratitud del país» ${ }^{38}$.

Los legisladores restauracionistas, persuadidos por los éxitos de las experiencias europeas, comenzaron a adoptar medidas en las que, por primera vez y de forma específica, se atendía a la formación teórico-práctica de las jóvenes. En este sentido, en 1907 se promulgó el Real Decreto de 25 de octubre sobre la organización central de los servicios de Agricultura y Ganadería ${ }^{39}$. Diez años más tarde, en agosto de 1917, se aprobó un nuevo real decreto. Esta disposición contemplaba la enseñanza de la mujer a través de las cátedras ambulantes. Pretendía, a través de ellas, perfeccionar sus conocimientos agrícolas a fin de que "por la práctica — en condiciones productivas y modernas- de las industrias sericícola, avícola, apícola y otras semejantes, contribuyera al aumento de los rendimientos del patrimonio familiar, empleando sus actividades en funciones adecuadas a su sexo y en alto grado fomentadoras del bienestar de la familia» ${ }^{40}$.

No fue, sin embargo, hasta la dictadura de Miguel Primo de Rivera cuando la enseñanza agrícola de las mujeres campesinas recibió un importante impulso. En esos años se trataron de imitar los proyectos emprendidos por países como Bélgica. La intención no era otra que, de un lado, revitalizar el papel de la mujer en la agricultura como un factor decisivo del proceso de modernización y aumento de la producción del sector agrícola. Su temprana educación, en la escuela primaria, contribuiría a ese proceso y frenaría su

\footnotetext{
Sánchez (1922): 141-142.

Sánchez (1922): 141-173.

Id., 142.

Id., 173.

Gaceta de Madrid, núm. 304, 31 de octubre de 1907.

Gaceta de Madrid. núm. 222, 10 de agosto de 1917, pp. 390-400.
} 
salida del campo y de la aldea. Para ello, y revestidas de un discurso patriótico y exaltador de la vida y de las virtudes del campo, se adoptaron medidas como las que indicamos a continuación. Se potenció la figura del maestro y la maestra especialista en una serie de contenidos que podemos considerar englobados dentro de la formación profesional rural. Para el nuevo régimen, los maestros y las maestras rurales tenían la «noble misión de forjar el alma de la campiña. De formar las juventudes de los pueblos y las aldeas. Formación familiar, agrícola, moral y social $»^{41}$. El Gobierno emprendió también la reforma de la escuela rural primaria. En los planes de estudios de los niveles inferiores del sistema educativo, introdujo la enseñanza de Nociones de Agricultura para los niños, y de Economía Doméstica Agraria para las niñas. La escuela debía iniciar la formación profesional del labrador y su compañera tempranamente, procurando que los niños y las niñas saliesen de la escuela dotados de un poderoso sentimiento de apego al terruño y

[...] con el espíritu abierto a toda innovación, instruidos en las verdades primordiales de la Ciencia agronómica moderna, con espíritu y hábitos de observación..., y preparados para entender y aprovechar los consejos y las experiencias de los agrónomos y los vulgarizadores científicos. Y si con esto lograra el maestro que el niño rural sintiera las satisfacciones y alegrías que proporciona la vida del campo; si consiguiera que se encariñara con la tierra, la bendita tierra que lo vio nacer, habría realizado la obra más hermosa y patriótica que la sociedad puede pedirle ${ }^{42}$.

En el quinquenio 1925-1930, y especialmente durante 1927, la Administración central impulsó fundamentalmente los aprendizajes agrícolas más especializados para ambos sexos, introduciendo las enseñanzas de Viticultura en veinte escuelas nacionales de la provincia de Toledo; las de Apicultura en treinta y siete instituciones educativas de veinticuatro provincias españolas; las de Avicultura en treinta y un colegios rurales de Castilla, León, Cataluña y Madrid; y las de Sericicultura en cuatrocientos centros primarios, muy repartidos por toda la geografía española, aunque con predominio de la zona levantina (Castellón, Alicante y Murcia) y el sureste de España (Granada). Asimismo, aprobó un real decreto el 26 de junio de 1924, referente a las escuelas agrícolas ambulantes para la enseñanza teórico-práctica de los y las jóvenes ${ }^{43}$.

\footnotetext{
Nogués Sardá (1925): 1.

Id., 3.

43 La Tierra. Órgano de la Federación de Sindicatos Católico-Agrarios de Córdoba, núm. 107, 30 de abril de 1926.
} 
En líneas generales, todos estos proyectaban una visión tradicional de la mujer en su función de esposa y madre, base de la familia y relegada al espacio doméstico. El hogar y la familia constituían el centro de la actividad femenina, en tanto la mujer era vista como reproductora biológica y social. La maternidad fue entendida como una función política y medio decisivo para la recuperación demográfica y de la raza. Es esta imagen la que impregnó las políticas educativas dirigidas a la mujer rural, y el fin primordial fue contribuir al asentamiento de la familia, evitando el éxodo del campo. Las actividades difundidas entre las amas de casa del medio rural podían considerarse una extensión del trabajo doméstico cotidiano afianzando y extendiendo a su vez las explotaciones de tipo familiar, sin perjuicio de su coexistencia con los grandes latifundios. La mujer rural fue interpelada, pues, como centro de la familia, considerada esta como base de la sociedad, pero también como portadora de nuevos valores y como colaboradora en la producción de la explotación agrícola para lograr el máximo rendimiento con los elementos a su alcance.

Las experiencias bélicas sufridas por la mayor parte de los países europeos desde fines del siglo XIX, pero sobre todo la gran tragedia colectiva que significó la Gran Guerra, impulsaron entre las derechas nacionalistas, autoritarias, corporativas o fascistas la constitución de amplias asociaciones patrióticas. Muchas de ellas estuvieron orientadas a fomentar una nueva ética de sacrificio a la patria y a lograr una eficaz difusión entre la población de aquellos valores espirituales más hondamente enraizados en la tradición que, mediante la apelación a la unidad orgánica de todos los componentes de la nación, mejor contribuirían a su robustecimiento. La mujer, y muy preferentemente la mujer campesina, comenzó a constituirse en un preciado objeto de movilización por parte de esas mismas sociedades patrióticas.

\section{SENSIBILIZACIÓN PATRIÓTICA, MOVILIZACIÓN POLITICA Y ENCUADRAMIENTO ASOCIATIVO DE LAS MUJERES CAMPESINAS}

En un periodo de intenso auge de las doctrinas nacionalistas instaladas en la propugnación del conservadurismo, el agrarismo y el tradicionalismo, concebidos como antídotos eficaces contra los estigmas disolventes y debilitadores del sentimiento patriótico, el rescate del universo de valores tradicionales encerrado en el mundo agrario, y la especial atención prestada a las mujeres campesinas como quintaesencia de los más profundos sentimientos identificativos del «ser nacional», se convirtieron en poderosas armas de movilización política y social esgrimidas por un heterogéneo y abigarrado universo de formaciones políticas, asociaciones profesionales y sociedades patrióticas preferentemente 
ubicadas en el amplio espectro del conservadurismo autoritario, el tradicionalismo católico o el nacionalismo integral de raíz antiliberal. Los discursos difundidos desde las derechas antiliberales, católico-corporativas o fascistas en defensa de la mujer rural se convirtieron en fuertes corrientes de pensamiento orientadas hacia su sensibilización patriótica, su movilización política y su encuadramiento en poderosas asociaciones de signo marcadamente reaccionario, antizquierdista e incluso antiparlamentario.

En España, pese a las peculiaridades de su proceso industrializador y pese a no haber participado en el enfrentamiento bélico de la Gran Guerra, también se registraron, con mayor o menor intensidad, muchos de los procesos descritos. Tras la debacle de 1914-1918, la apelación al mundo rural dejó definitivamente de constituir únicamente un referente esteticista o sentimental para convertirse en material de consumo político tanto para reaccionarios como para los más sofisticados adalides de la revolución conservadora. El discurso ruralista quedó desde muy pronto incardinado en aquel otro de corte profundamente ultracatólico y espiritualista que defendía una determinada reinterpretación tradicionalista y providencialista de la historia de España. En un proceso de decantación lento pero constante, la exaltación de las virtudes campesinas y el medio rural se convirtieron en ingredientes relevantes dentro de propuestas políticas más concretas, como el catolicismo social, el ultranacionalismo y el fascismo. De ahí que nosotros nos refiramos a dicho discurso de la ideología de la "soberanía campesina» como «nacional-ruralista» o «nacional-ruralismo» ${ }^{44}$. Y es que en la «identidad nacional» y en el "proyecto nacionalizador» de corte autoritario y antiliberal que forjó la extrema derecha española en el periodo de entreguerras, lo rural ocupó, paradójicamente en un mundo lanzado al progreso técnico, un lugar primordial. De tal manera que el significado de lo puramente español e hispano se «redefinió» a partir de múltiples referencias, materiales y simbólicas, que tenían su origen en la tierra y el mundo rural y campesino.

Por consiguiente, también en nuestro país fue emergiendo desde los comienzos del siglo XX una nueva derecha nacionalista de signo integralista, organicista, corporativista, fascista y antiliberal, que concibió a la mujer rural

44 El concepto «soberanía campesina», popularizado en España por Eduardo Sevilla Guzmán en la década de 1970, viene a significar el proyecto de idealización de las relaciones de producción en la agricultura, y cómo exaltando al campesinado, la agricultura era presentada no como una mera actividad económica, sino más bien como una forma superior de existencia que custodiaba la esencia de las virtudes étnicas y nacionales de España. El autor extrae este término de un discurso de Mussolini de febrero de 1921. Sevilla Guzmán (1979): 183-216. 
como un segmento de la población agraria altamente susceptible de ser sensibilizado y movilizado. Fue esa misma derecha la que elevó a la mujer rural a la categoría de objeto preferente en su labor de propagación de aquellos discursos exaltadores de un nuevo ideal patriótico asentado sobre una interpretación espiritualista y tradicionalista de la nación, capaz de contrarrestar el avance de las izquierdas marxistas y anarquistas o la amenazadora difusión del laicismo, el ateísmo, el materialismo individualista o el internacionalismo antipatriótico.

En este contexto de fobias e incertidumbres irrumpió el «nacional-ruralismo» con su idealización de las relaciones y condiciones del mundo rural. Con la esperanza de detener el cuestionamiento de los valores sociales y culturales decimonónicos de autoridad, orden y jerarquía — de clase y de sexo-, así como el flujo de mujeres de la tierra a las zonas urbanas, aquel discurso, diseminado entre la sociedad rural española por parte de las organizaciones campesinas y las formaciones políticas conservadoras y reaccionarias (el Partido Agrario Español, la CEDA, Falange Española), y sustentado en la concepción antimoderna, romántica y decimonónica según la cual el mundo rural era el baluarte donde se albergaban los valores ancestrales del sentimiento nacional, frente a la degradación progresiva que sobre todos ellos venía operando el avance imparable de la cultura urbana y la amenaza que se cernía sobre la estabilidad del viejo orden ${ }^{45}$, desplegó una visión esencialmente negativa y patológica de la mujer moderna y de la ciudad. Si a la primera la mostró como un sujeto rebelde, contraria al mandato impuesto y también a las fronteras de género, a la segunda la pintó como un espacio nocivo y desolador dentro del cuadro de la modernidad. El discurso "nacional-ruralista» hizo una simbiosis a partir de estas dos consideraciones: mujer moderna y ciudad. De esta forma indicaremos cómo las mujeres del campo y las mujeres de la ciudad fueron conceptualizadas siguiendo los mismos parámetros analíticos y definitorios que aquella relación romántica y dicotómica, naturaleza-sociedad, apuntada anteriormente. El «nacional-ruralismo» entendía a las mujeres urbanas, entregadas a las costumbres y gustos modernos, como irracionales, estériles e inmorales. Situadas fuera de una naturaleza rural idealizada (de una naturaleza femenina ideal, subordinada), las mujeres modernas de la ciudad estaban en la esfera de lo perverso y desviado, causando el declive de la población y otras consecuencias morales e higiénicas negativas e irreparables. Por el contrario, las mujeres campesinas fueron glorificadas. Ellas no estaban deslumbradas por las maléficas "luces de neón" de la ciudad, ni alienadas por pasatiempos inútiles. Tampoco estaban corrompidas por las modernas propuestas políticas difundidas en las urbes industriales que pretendían subvertir

45 Pan-Montojo (2005): 191. 
la vida tradicional y equiparar a los dos sexos. Su espíritu, como la naturaleza, era prístino y noble. Ellas fueron definidas entonces como las «verdaderas mujeres de España ${ }^{46}$. Las mujeres del mundo rural fueron erigidas de esta forma en símbolo de lo auténtico, de lo espiritual, de la traditio, valores esenciales de la «España eterna»"

Pero el «nacional-ruralismo» no se conformó únicamente con proyectar una imagen idílica de las mujeres del campo. Sabedores de la trascendental coyuntura histórica que se abrió después de la Primera Guerra Mundial, los miembros de las derechas antiliberales pronto reconocieron la importancia que podía llegar a tener la movilización público-política de las mujeres del campo. Con el fin de hacer de ellas «buenas campesinas», en el doble sentido de «buenas españolas» $\mathrm{y}$ «buenas amas domésticas», las integró en un proyecto más amplio que tenía que ver, de un lado, con la nacionalización de la población femenina en unos valores patrióticos y ultracatólicos — valores procedentes del mito de las "dos Españas" y del "peligro comunista", dos conceptos muy arraigados entre los políticos autoritarios- ${ }^{48}$, y de otro, con la regeneración de la sociedad a través de la educación ${ }^{49}$.

El discurso «nacional-ruralista» incorporó el «nuevo modelo de mujer»y la nueva «identidad cívica femenina» que la derecha radical había forjado en los años veinte y, sobre todo, en los años treinta tras la proclamación de la Segunda República ${ }^{50}$. Un nuevo modelo y una nueva identidad que, aunque seguían envueltos en un lenguaje de género tradicional y reaccionario hacia las propuestas de igualdad, no circunscribían a la mujer al hogar (propio del modelo liberal), sino que le conferían a esta una proyección y una función públicas importantes. A través de un rico poso ideológico, forjado en las lecturas y relecturas de la obra de los historiadores tradicionalistas del siglo XIX, y de los intelectuales europeos de la derecha antirrevolucionaria y fascista de comienzos del siglo $\mathrm{xx}^{51}$, las derechas reaccionarias españolas procedieron a

46 El pueblo: semanario social y agrario. Año I, núm. 22, 1928, julio 16, p. 3.

47 José María Pemán: «Las mujeres y las costumbres», Ellas. Semanario de las mujeres españolas, 2 (1932), p. 1.

48 García (2005) y Quiroga (2000): 211.

49 Este proyecto queda constatado en varios números, de entre 1933 a 1935, de una publicación periódica: CEDA. Órgano de la Confederación Española de Derechas Autónomas.

50 Las culturas políticas republicanas también utilizaron la prensa como un vehículo apropiado para forjar entre las mujeres una identidad colectiva femenina, en este caso, republicana y secularizada. Véase en este sentido Ramos (2010): 102.

51 Morodo (1980): 165-166; Álvarez (1997): pp. 35-67; González (1994, 1999: 98-101). 
«politizar» y «ensanchar» los roles y las obligaciones de las mujeres católicas españolas. Para la nueva derecha radical del periodo de entreguerras, las féminas españolas estaban al servicio de la patria y tenían, en consecuencia, que contribuir a "hacer patria» ${ }^{52}$. Este «hacer patria» consistía, entre otras cosas, en defender activamente unos valores que se encontraban amenazados por republicanos, socialistas, comunistas, anarquistas, masones y separatistas ${ }^{53}$. Cuantos se identificaron con los lenguajes políticos autoritarios y ultraconservadores enaltecieron las virtudes consideradas «propias» de la naturaleza femenina (obediencia, discreción, delicadeza, decencia, orden y devoción) por considerarlas armas poderosas que estaban esperando ser utilizadas para combatir a los enemigos (externos e internos) de España, máxime cuando se instauró en el país el inesperado régimen democrático republicano. A las mujeres «católicas y patrióticas» se las mostró, desde entonces, provistas de otras virtudes y valores asociados hasta ese momento al sexo masculino. La «nueva mujer católica» pasó a ser de esta forma valiente, heroica, decidida, incansable... pero siempre diferente de la degenerada y libertina "mujer moderna» de las ciudades occidentales.

Para la extrema derecha, las campesinas españolas eran profundamente cristianas, lo que quería decir «antisocialistas». De ahí que ellas, convenientemente preparadas y organizadas, pudieran asestar un duro golpe a los planes socialistas de descristianización y socialización de los campos de España ${ }^{54}$. Tanto la Iglesia católica como la derecha confesional antirrepublicana, inspiradas en el programa regeneracionista del catolicismo social, y en los ejemplos que le brindaban otros países europeos ${ }^{55}$ — no nos encontramos en consecuencia ante un hecho aislado-, patrocinaron la creación de las llamadas Ligas Católicas de Mujeres Campesinas ${ }^{56}$. Su fundación tenía un doble

52 "Las mujeres agrarias deben estar alerta», Ideal Agrario, 12 de enero de 1933, p. 1.

53 «Organicemos a las mujeres campesinas», El Pueblo. Semanario Social y Agrario, 16 de julio de 1928.

54 "Llamamiento a las mujeres campesinas. La organización se hace indispensable», Ideal Agrario, 20 de enero de 1933, p. 1.

55 Consúltese, al respecto Jones (2009); Scheck (2004) y Bridenthal (1993).

56 El 15 de febrero de 1935 podía leerse la siguiente noticia en la publicación periódica $C E D A$ : «Recientemente acaba de iniciar la Asociación Femenina de Acción Popular de Madrid, una obra que ya se extiende por la provincia de Madrid y ha de implantarse en España entera: es la Liga de Campesinas, cuyo fin es realizar en los hogares de los pueblos españoles una labor de educación moral y material, de higiene, de comunicar una sana alegría a las familias labradoras, de facilitar y propagar enseñanzas agrícolas apropiadas a la actividad de la mujer y del hogar» (p. 17). 
objetivo. Primeramente, y por la razón indicada, «desarrollar el progreso religioso, moral y social de sus asociados». Con su devoción y religiosidad, la mujer campesina organizada en aquellas Ligas se convertiría en el dique más poderoso contra el cual se estrellarían los embates del socialismo y el comunismo. Y en segundo lugar, las Ligas Campesinas femeninas aportarían conocimientos suficientes a las mujeres del campo para convertirlas en auténticas "amas y señoras de su hacienda». La instrucción las capacitaría para desempeñar mejor el rol que la naturaleza les había asignado: ser esposas, madres, criar a los hijos y administrar las labores del hogar. Pero también les conferiría una formación profesional adecuada para lograr el autoabastecimiento de las explotaciones agrarias familiares y su óptima gestión. De tal manera que, junto a lecciones específicas sobre religión y moral cristiana, corte y confección, el cuidado de los niños, la alimentación, la higiene y la administración doméstica, las Ligas impartieron, con motivo de los cursos que organizaron en granjas escuelas como la de Villa Teresa en Valladolid, lecciones referidas a la jardinería, a la apicultura, a la cría de conejos, vacas, ovejas y aves de corral, a la fabricación de embutidos, conservas, licores y artesanías, a la apertura de surcos en la tierra para la sementera, a la poda, al riego, y hasta sobre el saber "leer el azul del cielo»" Se trataba de aportar variados y complejos conocimientos a las agricultoras, siguiendo lo apuntado por los ingenieros agrónomos, para despertar en ellas «el amor al campo y a la riqueza oculta de las pequeñas industrias que de la agricultura se derivaban». Pero al mismo tiempo, para "ennoblecer» el hogar campesino y convertirlo en un espacio de bienestar provisto de las comodidades necesarias. Únicamente conociendo cuáles eran sus deberes y sus funciones en la explotación agrícola familiar, según argumentaban los principales artífices de las Ligas Campesinas femeninas, las mujeres podrían defender más adecuadamente los intereses agrarios. Y lo que era más importante, la instrucción de las campesinas en todos aquellos saberes las haría desistir de su deseo de abandonar el campo para marcharse a la ciudad «en busca de una felicidad ficticia».

\section{A MODO DE CONCLUSIÓN. LA GLORIFICACIÓN DEL MUNDO RURAL-CAMPESINO Y SUS MUJERES DURANTE LA PRIMERA ETAPA DEL FRANQUISMO}

La guerra civil y la dictadura franquista "ponderaron» todo cuanto llevamos dicho sobre el discurso «nacional-ruralista». El discurso de la «soberanía

$57 A B C, 26$ de julio de 1933, p. 6. 
del campesinado» estuvo presente desde el mismo día en que se consumó el golpe de estado contra la Segunda República. Dicho discurso se presentó como un indiscutible dispositivo de movilización y cohesión social del bando sublevado. Un dispositivo que recolectó y canalizó toda la animadversión que existía entre el campesinado hacia el régimen republicano y su política reformista.

Aunque antes de julio de 1936 el discurso «nacional-ruralista» ya estaba prácticamente conformado, al iniciarse la guerra este se revistió con nuevos elementos que conectaban más claramente al franquismo con otros regímenes totalitarios. La intensificación del carácter trascendente, el ultranacionalismo y el pretendido afán revolucionario hicieron que la idealización del mundo rural, en contraposición a un universo urbano deshumanizado, alcanzara entonces límites extravagantes ${ }^{58}$. La dictadura franquista, al igual que el fascismo italiano a través de la Bonifica Integrale o el Tercer Reich alemán a través de Blut und Boden (Sangre y Tierra) y la política de Richard Walther Darré, llevó a cabo en su fase de instauración un proyecto de nacionalización de los españoles - no exento de contradicciones - en el que la exaltación del campesinado y la tierra ocuparon un lugar de primerísimo orden. Y evidentemente, en ese proyecto, la reivindicación de las tradiciones campesinas, del folklore y de un mundo rural idealizado se transmutaron en elementos de primer orden. Así, el enaltecimiento de las virtudes campesinas y el medio rural se convirtieron en ingredientes relevantes del bando rebelde. La ruralización fue interpretada, de la misma forma que se había hecho en la Italia fascista y en la Alemania nazi, no solo en términos pragmáticos y de política agraria (de colonización, de regulación de los mercados agrarios, de modernización productiva, de intensificación de determinados cultivos), sino además como un instrumento moral que podía reinyectar el ideal de la «lucha» en la vida nacional. Mientras que el ciudadano urbano se presentaba por los fascismos como un agente social "corrupto", envilecido por las comodidades modernas y la indulgencia de los pasatiempos burgueses e improductivos, el campesino tenía que «luchar» por cultivar su tierra; solo con privaciones podía vivir de lo que la tierra producía. El campesino, idealizado de esta manera, era retratado viviendo una vida simple y modesta, modelada por su ruda y ardua tarea de domesticar y controlar la naturaleza. En el ideario fascista, la agricultura simbolizaba la lucha por crear un nuevo orden ${ }^{59}$. El «nacional-ruralismo» franquista adoptó parte de este ideario que ya estaba presente en el discurso agrarista de Falange Española de las JONS. Su postura antiurbana la justificó

58 Richards (1999): 143.

59 Binde (1999): 768. 
con múltiples referencias a un trabajador agrícola idealizado que se ganaba la vida honestamente y beneficiaba a la nación por medio de su trabajo. Al igual que el fascismo mussoliniano, el régimen de Franco buscó crear un nuevo, «sano» y heroico hombre. Este era en buena medida un trabajador agrícola, un labrador, en lugar del individuo liberal, laissez-faire y burgués producido por las finanzas y el capital, e infectado por los valores urbanos y las tentaciones consumistas $^{60}$. El labrador glorificado por el franquismo se contraponía también al pernicioso modelo del trabajador urbano. En este sentido, la dictadura se apropió de aquellas representaciones que habían forjado en España el catolicismo social y las culturas antiliberales y tradicionalistas sobre el obrero de la ciudad. De manera particular, el franquismo propinó a los trabajadores urbanos desmesurados y abyectos calificativos. Hasta bien entrada la década de los cuarenta, el régimen franquista mostró al proletariado de las ciudades no solo como un colectivo social infectado completamente por el virus de la izquierda y el veneno de la revolución socialista, sino que lo puso además al servicio de poderosas e imaginarias fuerzas que maquinaban de manera ruin y conspirativa contra el esencialismo hispanista más hondamente asentado sobre las tradiciones del catolicismo, el patriotismo, la jerarquía o la defensa de la raza.

El régimen franquista trazó de esta manera una gruesa línea divisoria entre dos mundos antagónicos. En los años que duró el conflicto civil y en los inmediatamente siguientes, el franquismo compartió con el resto de los fascismos un desprecio absoluto hacia el mundo urbano y sus centros capitalinos, a los que consideraba corruptos y sometidos a una irrefrenable degradación moral. Tal y como acabamos de señalar, para los insurgentes del bando rebelde las ciudades se habían convertido en el reducto en el que se concentraban los integrantes de la militancia izquierdista, comúnmente conocidos como «los marxistas», la «barbarie comunista», las «hordas marxistas asesinas», «los bárbaros asiáticos» y un largo etcétera. Esta caricaturizada imagen era incompatible con el proyecto palingenésico que aquellos ambicionaban instaurar. Las proclamas regeneradoras y antiizquierdistas catapultadas por la espiral de odio, muerte y venganza que se desató durante la guerra, llevaron al franquismo a condenar el mundo urbano mientras que, por el contrario, el mundo rural fue objeto de todo tipo de alabanzas. Según se desprendía de la lectura de innumerables relatos absolutamente idealizados que vieron la luz entre 1936-1939, así como en la posguerra, el campo conservaba aún el carácter espiritual español y las esencias ancestrales de la nación hispana. Según se afirmaba en los mencionados relatos, la masa agraria era presentada como un vasto grupo apolítico,

$60 \quad$ Ipsen (1996): 6. 
joven, libre y alegre, ajeno a los egoísmos y mezquindades de la masa urbana. Para la ideología "nacional-ruralista» franquista, muy próxima en este sentido al ideario völkisch y al romanticismo agrario del Blut und Boden, los campesinos y las campesinas españoles eran los depositarios de los más esenciales y admirables valores morales y atributos raciales de la casta hispana.

La reagrarización del país y la sujeción del genio hispano al suelo patrio, junto a la regeneración integral de los españoles, constituyeron, pues, elementos fundamentales en la configuración del Nuevo Estado franquista. ¿Qué lugar ocupó la mujer campesina en el proyecto «nacional-ruralista» de exaltación del campesinado difundido durante primer franquismo? ¿Cuál fue el papel que el régimen franquista asignó a las agricultoras en su política social-agraria? Para dar respuesta a estas preguntas retomaremos lo apuntado para el periodo anterior al golpe de Estado del 18 de julio. Así, la dictadura trató de hacer realidad los planes diseñados por las fuerzas políticas reaccionarias de convertir a la población rural femenina en «buenas campesinas», es decir, piezas básicas de las explotaciones agrarias familiares. Un deseo que, como veremos, iba más allá de los simples anhelos por restablecer cierta normalidad en la calamitosa situación del campo español, lograda mediante el restablecimiento del orden social alterado por la reforma agraria republicana y las colectivizaciones puestas en pie durante la guerra.

Tras el conflicto civil había que responder a las duras exigencias que imponía la política autárquica de autoabastecimiento. En este sentido, el franquismo amplificó y redobló los esfuerzos para conseguir el adoctrinamiento y nacionalización de las mujeres campesinas en aquel ideario «nacional-ruralista» de preguerra que, durante la Guerra Civil, se configuró en un vigoroso instrumento de movilización política, hasta convertirse en una poderosa arma, capaz de influir en la modulación de los pensamientos, las actitudes y los comportamientos de una extensa gama de actores individuales y colectivos comprometidos en una lucha encarnizada contra la experiencia democrática de la Segunda República. Aquella movilización había que mantenerla después del 1 de abril de 1939. En juego estaba la propia supervivencia del régimen franquista. La dictadura convirtió entonces a las mujeres campesinas en símbolo del coraje y la vigilancia, en la salvaguardia de las puertas y tesoros de la «España eterna». Ellas eran las «Leonas de Castilla».

Pero con discurso y simbología no se respondía a las exigencias de la política económica autárquica. La dictadura asumió la consigna ultranacionalista y fascista del «esfuerzo colectivo». Todos los «brazos» contaban para acometer ese esfuerzo y lograr la prosperidad de la patria. En el caso de las mujeres del campo, en el programa agrario del franquismo se constata el mismo deseo que ya había sido anteriormente expresado por las Ligas Católicas de Mujeres 
Campesinas, preocupadas por la "profesionalización» de las tareas que las mujeres venían desempeñando desde antaño en la actividad agrícola, aunque confiriéndoles una dimensión nueva. Aquellas tareas debían ser enseñadas como si de una profesión se tratase, con el fin de adquirir unas cotas de perfección que garantizasen la estabilidad social y la prosperidad económica. Profesionalización de tareas que tenía que ver con la adquisición de múltiples conocimientos que abarcaban desde la agronomía (para favorecer la intensificación de la producción agraria con el fin de asegurar el abastecimiento alimentario de las ciudades), a la puericultura y la eugenesia (para disminuir la mortalidad infantil y favorecer el mejoramiento de la raza). La transmisión de estos amplios conocimientos sobre economía doméstica fue llevada a cabo por la Hermandad de la Ciudad y del Campo de la Sección Femenina de Falange. Esta institución sería utilizada por el franquismo como un eficaz mecanismo de propaganda política y nacionalización de las campesinas en los principios «nacional-ruralistas» que hemos tratado de describir ${ }^{61}$.

\section{BIBLIOGRAFÍA}

Álvarez Junco, J. (1997). El nacionalismo español como mito movilizador. Cuatro Guerras. En R. Cruz y M. Pérez Ledesma (eds.). Cultura y movilización en la España contemporánea (pp. 35-67). Madrid: Alianza Editorial.

Applegate, C. (1990). A Nation of Provincials: The German Idea of Heimat. Berkeley: University of California Press. Disponible en: https://doi.org/10.1073/pnas.87.1.51.

Aresti, N. (2001). Médicos, donjuanes y mujeres modernas. Los ideales de feminidad y masculinidad en el primer tercio del siglo XX. Bilbao: Universidad del País Vasco.

- (2010). Masculinidades en tela de juicio. Hombres y género en el primer tercio del siglo XX. Madrid: Cátedra.

Arnáiz de las Revillas, A. (1999). La cooperación, la asociación y las redes como herramienta fundamental de trabajo para promover la integración de la mujer en el desarrollo rural. En La mujer: clave del desarrollo rural (pp. 65-69). Jaén: Junta de Andalucía, Consejería de Agricultura y Pesca de Andalucía.

Binde, P. (1999). Nature versus city: landscapes of Italian Fascism. Environment and Planning D: Society and Space, 17 (6), 761-775. Disponible en: https://doi.org/10.1068/d170761.

Blackbourn, D. (1980). Class, Religion and Local Politics in Wilhelmine Germany. The Centre Party in Württemberg before 1914. New Haven and London: Yale University Press.

Blasco Herranz, I. (2013). Mujeres y Nación: Ser Españolas en el siglo Xx. En J. Moreno Luzón y X. M. Núñez Seixas (eds.). Ser Españoles. Imaginarios nacionalistas en el siglo XX (pp. 168-206). Madrid: RBA Editores.

61 Marías (2011). 
Bridenthal, R. (1993). Organized Rural Women and the Conservative Mobilization of the German Countryside in the Weimar Republic. En L. E. Jones y J. Retallack (Eds.). Between Reform, Reaction and Resistance. Studies in the History of German Conservatism from 1780 to 1945 (pp. 375.405). Oxford: Berg.

Calvo, J. L. (2001). Escritores aragoneses de los siglos XIX y XX. Zaragoza: Rolde.

Camarero, L. A. (1993). Del éxodo rural y del éxodo urbano: ocaso y renacimiento de los asentamientos rurales en España. Madrid: Ministerio de Agricultura, Pesca y Alimentación.

Capel, R. M. a (1980). La mujer española en el mundo del trabajo, 1900-1930. Madrid: Fundación Juan March.

Cobo Romero, F. (2010). The Red Dawn' of the Andalusian Countryside. Peasant Protest during the 'Bolshevik Triennium', 1918-1920. En F. J. Romero Salvadó y A. Smith (eds.). The Agony of Spanish Liberalism. From Revolution to Dictatorship 1913-23 (pp. 121-144). London: Palgrave Macmillan.

Confino, A. (1997). The Nation as a Local Methaphor: Württemberg, Imperial Germany and National Memory, 1871-1918. Chapel Hill: University of North Carolina Press.

De Roda y Jiménez, R. (1926). La emigración de los campos a las ciudades. Memoria premiada en el concurso celebrado con motivo del CL aniversario de la fundación de la Real Sociedad Económica Matritense de Amigos del País. Madrid: Imprenta de los Hijos de Tomás Minuesa de los Ríos.

Díez de Revenga, F. J. (1998). Poesía naturalista: el ruralismo premodernista de fin de siglo. En Y. Lissorgues (ed.). Realismo y naturalismo en España en la segunda mitad del siglo XIX (pp. 212-225). Barcelona: Université de Toulouse-le Mirail, Editorial Anthropos.

Elías de Molins, J. (1927). El abandono de la tierra en España. La población y el grande y pequeño riego. Barcelona: Perfectus Travesera.

Feliz, V. (1934). Jóvenes campesinos de Acción Católica y Social. Madrid: Razón y fe.

Fusi, J. P. (1991). La crisis de la conciencia europea. En M. Cabrera, S. Juliá, P. Martín (comps.). Europa en crisis, 1919-1939 (pp. 327-342). Madrid: Ed. Pablo Iglesias.

García Fernández, H. (2005). Historia de un mito político: el peligro comunista en el discurso de las derechas españolas (1918-1936). Historia social, 51, 3-20.

González Cuevas, P. C. (1994). Charles Maurras y España. Hispania, 54 (188), 993-1040.

- (1999). Acción Española. Teología política y nacionalismo autoritario en España (19131936). Madrid: Tecnos.

Ipsen, C. (1996). Dictating Demography. The problem of population in Fascist Italy. Cambridge: CambridgeUniversity Press. Disponibleen:https://doi.org/10.1017/CBO9780511581953.

Jones, E. B. (2009). Gender and Rural Modernity. Farm Women and the Politics of Labor in Germany, 1871-1933. Surrey and Burlington: Ashgate.

Lekan, T. M. (2004). Imagining the Nation in Nature. Landscape Preservation and German Identity, 1885-1945. Cambridge. Massachusetts: Harvard University Press.

Marías, S. (2011). Por España y por el campo: La sección femenina en el medio rural oscense (1933-1977). Huesca: Instituto de Estudios Altoaragoneses.

Martí Alpera, F. (1911). Las escuelas rurales. Gerona: Dalmáu Carles.

Molins, J. E. (1927). El abandono de la tierra en España. La población y el grande y pequeño riego. Barcelona: Perfectus Travesera.

Morodo, R. (1980). Acción Española. Orígenes ideológicos del franquismo. Madrid: Tucar. 
Motadel, D. (2008). The German Nature Conservation Movement in the Twentieth Century. Journal of Contemporary History. 43 (1), 137-153. Disponible en: https://doi. org/10.1177/0022009407084564.

Nogués Sardá, A. (1925). El campo escolar agrícola. La Tierra: Órgano de la Federación de Sindicatos Católico-Agrarios de Córdoba, 5 (92), 3.

Núñez Seixas, X. M. y Umbach, M. (2008). Hijacked Heimats: national appropriations of local and regional identities in Germany and Spain, 1930-1945. European Review of History, 15 (3), 295-316.

Ortega López, T. Ma (2010). Culturas liberales y catolicismo en la génesis del antifeminismo franquista. Historia Social, 67, 155-171.

Pan-Montojo, J. (2005). Apostolado, profesión y tecnología. Una historia de los ingenieros agrónomos en España. Madrid: Asociación Nacional de Ingenieros Agrónomos.

Pestana, A. (1901). La enseñanza agrícola de la mujer. Boletín de la Institución Libre de Enseñanza. XXV, 497, 225-228.

Puhle, H. J. (1986). Lords and Peasants in the Kaiserreich. En R. G. Moeller (ed.). Peasants and Lords in Modern Germany. Recent Studies in Agrcultural History (pp. 81-109). London. Sydeny: Allen and Unwin.

Quiroga Fernández de Soto, A. (2000). La idea de España en los ideólogos de la dictadura de Primo de Rivera. El discurso católico-fascista de José Pemartín. Revista de Estudios Políticos, 108, 197-224.

Ramos, M. D. (2002). Neutralidad en la guerra, paz en la Dictadura. Las transformaciones en la vida cotidiana (1917-1930). En A. Aguado y M. D. Ramos, Modernización de España (1917-1939). Cultura y vida cotidiana (pp. 91-152). Madrid: Síntesis.

- (2010). Las primeras modernas. Secularización, activismo político y feminismo en la prensa republicana: Los Gladiadores (1906-1919). Historia Social, 67, 93-112.

Redonet y López, L. (1916). Política agraria (conferencia pronunciada el 29 de enero). Madrid: Real Academia de Jurisprudencia y Legislación Establecimiento Tipográfico de Jaime Ratés.

Retallack, J. N. (1988). Notables of the Right. The Conservative Party and Political Mobilization in Germany, 1876-1918. Boston: Unwin Hyman.

Richards, M. (1999). Un tiempo de silencio. La guerra civil y la cultura de la represión en la España de Franco, 1936-1945. Barcelona: Crítica.

Rosell, J. (1907). Paseos por el campo. El Progreso agrícola y pecuario, 527, 179-181.

- (1909). Desde una granja. El Progreso agricola y pecuario, 656, 751-752.

Ruiz de Tudanca (1928). Movimiento agrario en España. Revista Católica de Cuestiones Sociales, 399, 179-188.

Sánchez Anido, J. (1922). Educación campesina. Madrid: Imprenta de Perlado, Páez y C. ${ }^{a}$ Quintana.

Scheck, R. (2004). Mothers of the Nation. Right-Wing Women in Weimar Germany. Oxford. New York: Berg.

Sevilla Guzmán, E. (1979). La evolución del campesinado en España: elementos para una sociología política del campesinado en España. Madrid: Península.

Ugarte, J. (1998). La Nueva Covadonga insurgente. Orígenes sociales y culturales de la sublevación de 1936 en Navarra y País Vasco. Madrid: Biblioteca Nueva. 
Urquijo-Goitia, J. R. y Paniagua, Á. (2011). Entender a Fermín Caballero. Poder, política y espacio rural en el siglo XIX. Historia Agraria, 53, 43-71.

Utrillo, J. (1952). El éxodo rural en Cataluña y zonas limítrofes. Reacciones de los centros nucleares. (Conclusión). Revista Internacional de Sociología, 38 (10), 391-436.

Vallejos Izquierdo, A. (2014). 'Fomento de la población rural' de Fermín Caballero: Ciencia Social y Gobierno. Empiria. Revista de Metodología de Ciencias Sociales, 29, 215-257. Disponible en: https://doi.org/10.5944/empiria.29.2014.12951.

Weindling, P. (1989). Health, Race and German Politics between National Unification and Nazism, 1870-1945. Cambridge: Cambridge University Press. 